\title{
КОМПЬЮТЕРНЫЙ ПОИСК ЛЕКАРСТВЕННЫХ СОЕДИНЕНИЙ С АНТИ-ВИЧ ЭФФЕКТОМ НА ОСНОВЕ АНАЛИЗА ПРОФИЛЕЙ ТРАНСКРИПЦИИ В Т ЛИМФОЦИТАХ
}

\author{
С.М. Иванов, О.А. Тарасова, Д.А. Филимонов, В.В. Поройков
}

Лаборатория структурно-функционального конструирования лекарств, ФГБНУ «НИИ биомедицинской химии имени В.Н. Ореховича», 119121, Россия, Москва, Погодинская улица, д. 10, стр. 8.

DOI: 10.19163/MedChemRussia2021-2021-178

E-mail:smivanov7@gmail.com

Вирус иммунодефицита человека (ВИЧ) является одной из важнейших причин смертности в России и мире. Современные подходы к терапии ВИЧинфекции снижают вирусную нагрузку, но не позволяют достигнуть полной элиминации вируса. Одним из направлений поиска новых способов терапии ВИЧ-инфекции является анализ взаимодействия ВИЧ с организмом человека. Известно, что степень контроля над виремией и скорость прогрессии заболевания различаются у разных пациентов, что, помимо прочего, может быть связано с разным функциональным состоянием CD4+ и CD8+ Т лимфоцитов [1, 2].

Целью данной работы являлась разработка подхода, включающего: (1) анализ профилей транскрипции в CD4+ и CD8+ T-лимфоцитах у пациентов C разной скоростью прогрессии ВИЧ-инфекции, принимающих и не принимающих антиретровирусные препараты; (2) поиск мастер-регуляторов (белков, которые могут активировать другие звенья сети молекулярных взаимодействий и опосредовать наблюдаемые изменения транскрипции генов по отношению к норме); (3) идентификация лекарственных соединений, потенциально способных действовать на выявленные мастер-регуляторы, на основе поиска в свободно-доступных базах данных и прогноза воздействия на мастер-регуляторы при помощи анализа «структура-активность». В результате мы идентифицировали новые потенциальные белки-мишени человека для терапии ВИЧ-инфекции, включая рецепторы интерлейкинов-2 и 4, интерферона гамма, хемокиновые рецепторы С-Х-С 2 и 4. Для идентифицированных мишеней выявлены лекарства - «кандидаты» для терапии ВИЧ-инфекции, включая миноциклин и глицирризиновую кислоту.

Исследование выполнено при поддержке Российского научного фонда, грант № 197510097.

\section{Литература}

[1] E. Gonzalo-Gil, U. Ikediobi, and R.E. Sutton. Yale J Biol Med. 2017, 90, 245-259.

[2] S. Ivanov, D. Filimonov, and O. Tarasova. Comput Struct Biotechnol J. 2021, 19, 2447-2459.

$$
-178-
$$

